\title{
Case Study Report on Distress in Water Tanks
}

\author{
A. Sujatha* \\ Bharath University, Selaiyur, Chennai-73, India; sujiash@yahoo.com
}

\begin{abstract}
Over head water tanks, made up of reinforced concrete are more common due to the fact that it can be easily cast in any desired shape and size. The durability of such tanks may get affected due to external agents like wind, air etc. and needs maintenance periodically. The corrosion of reinforcement is the major distress of any reinforced concrete structure, and these tanks also face the same problem. Once the corrosion of steel happens, the satisfactory performance of the reinforced concrete tanks gets affected and distress starts in the form of minor cracks. If left unchecked, the effects of corrosion may propagate further and may lead to structural failure in due course. In this case study, many overhead tanks made up of reinforced concrete were studied, and their types of distress along with remedial measures are suggested.
\end{abstract}

Keywords: Maintenance, Rehabilitation, Water Tanks

\section{Introduction}

Distress signals in the observed water tanks ranged from seepage, cracks etc in different parts of the water tanks. The corrosion effects in a water tank happens mainly due to seepage into the layer of concrete, considering the fact that the concrete is always in touch with the water on the inside of the wall thickness. Crack observations were noticed on different parts of the structure like the columns, ring beams, walls of the tanks etc A total of about 250 tanks were studied, which were located in different parts of the country. Cracks in the concrete columns, occurring in $16 \%$ of the tanks suggested that poor quality of construction was maintained.

\section{Case Study Findings}

The following are the reports of the case study ${ }^{1}$

\begin{tabular}{ll}
\hline Nature of problem & $\begin{array}{l}\text { Approximate Percentage } \\
\text { affected by the problem }\end{array}$ \\
\hline
\end{tabular}

Seepage in bottom side wall

ring beam concrete

Cracks in concrete column

16

Rusting in column concrete reinforcement

\begin{tabular}{ll}
$\begin{array}{l}\text { Deteriorated column concrete } \\
\text { Rusting in side wall/ring beam } \\
\text { reinforcement }\end{array}$ & 12 \\
$\begin{array}{l}\text { Deterioration in bottomside } \\
\text { concrete }\end{array}$ & 11 \\
$\begin{array}{l}\text { Cracks in bottom side wall } \\
\text { Rusting in top dop dome } \\
\text { reinforcement }\end{array}$ & 9.5 \\
$\begin{array}{l}\text { Deteriorated top dome } \\
\text { Cracks in plinth protection }\end{array}$ & 7.9 \\
Cracks in top dome & 5.85 \\
Shaft distress & 4.5 \\
Foundation settlement & 2 \\
Dampness in concrete column & 2 \\
\hline \multicolumn{2}{|l}{ Suggested Remedial Measures } \\
for Treating Distress
\end{tabular}

(i) For treating minor cracks, clean the surface with wire brush and remove dust with cloth and water.

(ii) $5 \mathrm{MM}$ thick rich mortar mix is to be applied on top of dome and sides of the ring beam.

*Author for correspondence 
(iii) For treating cracks on the water side, after cleaning with brush and removing the deposits, application of epoxy resin coating of thickness of about 100 micron to water proof the concrete.

(iv) For exterior surfaces after chipping away loose concrete, clean the surface with dilute hydrochloric acid, and clean the rust from the reinforcement by sand blasting.

(v) A new plinth protection is to be provided and the ingress of water to the foundation is checked.

\section{Conclusion}

Water tanks are important structures whose durability is to be checked to ensure its design life. Proper maintenance to already distressed members is a necessity.

\section{References}

1. Anna University, Chennai. Work Shop on maintenance and rehabilitation of buildings [Lecture Notes]; 1999. 